\title{
Interest Rate Liberalization and Commercial Banks Profitability: Evidence from China
}

\author{
Lai Ying ${ }^{1}$ \\ ${ }^{1}$ School of Economics in Central University of Finance and Economics, Beijing, P.R. China \\ Correspondence: Lai Ying, School of Economics in Central University of Finance and Economics, 39 South \\ College Road, Haidian District, Beijing, P.R. China. Tel: 86-186-0112-8216. E-mail: laiying.bj@ foxmail.com
}

Received: March 19, 2020

Accepted: April 13, 2020

Online Published: April 20, 2020

doi:10.5539/ijef.v12n5p90

URL: https://doi.org/10.5539/ijef.v12n5p90

\begin{abstract}
On the basis of the existence and development of commercial banks, enhanced profitability is a significant guarantee to improve the well-being of people and better exert the functions of commercial banks in promoting economic, social and production growth. Interest rate liberalization is one of the key factors which can affect the profitability of commercial banks. An empirical study is thus carried out on 16 Commercial banks (from 2007 to 2018) to analyze the impact of interest rate liberalization on the profitability of commercial banks. We draw main conclusions from this study: (1) the progress of interest rate liberalization has improved the profitability of banks. (2) This kind of impact is inverted U-shaped, that is, with the advancement of interest rate liberalization, the impact will be reversed in the future. (3) For banks of different sizes, the impact is different. Specifically, small and medium-sized banks are more sensitive to the liberalization of interest rates, while for larger banks, the impact is not strong.
\end{abstract}

Keywords: interest rate liberalization, profitability, commercial banks

\section{Introduction}

Enhancing profitability is the foundation for the existence and development of commercial banks, and also an important guarantee for better performing the functions of commercial banks in promoting economic, social and ecological development and continuously improve people's well-being. The liberalization of interest rate is an important factor affecting the profitability of commercial banks. The development of commercial banks in various countries proves that the liberalization of interest rate brings many development opportunities and risk challenges to commercial banks.

\subsection{Comprehensive Analysis}

For the dominant banks in Chinese financial system, especially commercial banks, interest rate liberalization can exerts a comprehensive and far-reaching impact on their profitability. In the process of interest rate liberalization, especially in its initial stage, commercial banks will suffer a relatively significant negative impact, such as narrowed spread on deposits and loans, declined profitability, increased relevant risks, and inadaptability for traditional business mode and internal management mode. But at the same time, interest rate liberalization can also bring development opportunities, or some positive influence, to commercial banks.

\subsubsection{Deposit and Loan Interest Rates Fall and Then Stabilize}

Generally, the deposit interest rate will be greatly restrained before interest rate liberalization, Therefore, in the early stage of interest rate liberalization, the deposit interest rate is higher than the loan interest rate, which will lower the interest spreads of deposit and loan and decrease the profit, leading to an impact on the commercial banks. As can be seen from the figure 1 below, China's loan interest rate fell by two times in 2012, with relaxed upper limit of deposit interest rate in its floating range, and expanded net interest margin of commercial banks. In 2013, loan control was liberalized, and between 2014 and 2017, the net interest margin of commercial banks continued to decline, and gradually stabilized after 2017. It can be inferred that deposit and loan spread fell first and then stabilized during the process of interest rate liberalization. 
2010-2019 NIM and Proportion of non interest income of Commercial banks

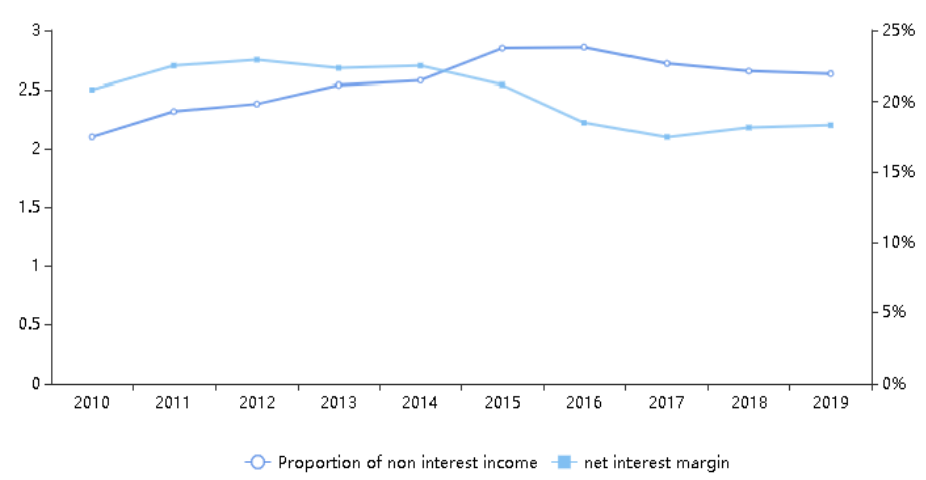

Figure 1. Change in NIM and proportion of non interest income of commercial banks from 2010 to 2019

\subsubsection{Loans Delivery Impulse Increased While the Loans Growth Rate Fell}

In response to the pressure of narrowing interest spread, commercial banks may increase the size of loans, especially the high-yield and high-risk loans, but the growth rate of total loans will decline. As net interest income has always been an important source of profit (accounting for 70-80\% of the total) for Chinese commercial banks, commercial banks must will vigorously carry out intermediary services to increase profits to cope with the decline in interest spreads of deposit and loan. Therefore, it offsets the decreased credit spread income with increased proportion of intermediary services income, and improves the profitability of banks.

\subsubsection{Increased Operating Risk and Yet-to-Be Improved Risk-Control Capacity}

Interest rate liberalization will increase the credit risk, interest rate risk and liquidity risk of commercial banks. In response to the decline in interest spreads of deposit and loan caused by interest rate liberalization, commercial banks will increase high-yield loans, which will inevitably expand credit risk. Besides, frequent interest rate fluctuations will increase interest rate risk, and unstable deposits will pose a potential liquidity risk. In the early 1980s, during the interest rate liberalization in the United States, credit crisis was triggered by the increased credit risk, interest rate risk and liquidity risk of banks.

\subsubsection{Transformation of Development Model}

Interest rate liberalization adds considerable pressure and difficulties to the transformation of the development mode, business mode and management mode of commercial banks. With the development of interest rate liberalization, commercial banks must change their original expansion-based development mode which mainly focused on seeking the scale and speed of loans and deposits, and shift to the intensive development mode with more emphasis on quality and efficiency. In terms of business mode, they should change from the mode of excessively relying on deposit and loan interest income and wholesale business income to a mode of vigorously developing retail business and intermediary services income. In terms of management mode, it is necessary to improve the asset and liability management, credit management, cost management and resource allocation management in order to adapt the transformation of development mode and business mode.

\subsubsection{Interest Rate Liberalization also Brought Development Opportunities to Commercial Banks}

Interest rate liberalization provides the basis and conditions for innovative products of banks, which can improve their customer service capabilities. Also, it will activate money market and bond market, and help banks optimize asset structure and increase capital business income. The development of capital market driven by interest rate liberalization will bring great opportunities for banks to carry out intermediary services such as bond issuance, underwriting, consultation, settlement and clearing. Moreover, the financial derivatives emerged with interest rate liberalization not only provide risk management tools for commercial banks, but also bring substantial investment income to banks.

\subsection{Review of Academic Researches}

In the banking sector, financial institutions are classified into deposit-taking ones and non-deposit-taking ones. Considering that commercial banks play a dominant and representative role in the banking industry in terms of their scale and influence, this paper introduces some instances of commercial banks and studies the impact of interest rate liberalization on the profitability of commercial banks. In the existing literature, most scholars believe that interest rate liberalization exerts a profound impact on the profitability of commercial banks, and can 
bring them certain opportunities and challenges. Challenges here refer to the considerable negative impact on commercial banks in the process of interest rate liberalization, especially in the early stage of that. Such negative impact could lead to narrowing interest spread between deposits and loans, declining profits and swelling risks, as well as inadaptation of traditional business modes and internal management modes. While the opportunities here are mainly reflected in urging the banks to actively manage assets and liabilities, optimize the structure of customers, make financial innovation, promote the development of intermediary services, and drive the strategic transformation of bank operations. For the academic circle, the focus is on how commercial banks manage risks and how their profit models are influenced by interest rate liberalization.

\subsubsection{Interest Rate Liberalization and Risk Management of Commercial Banks}

Wu Chengsong and Zhang Wenrui (2017) conducted an empirical analysis on the price competition, shadow banking business and risks for commercial banks in terms of liquidity risk and credit risk from the perspective of interest rate liberalization reform based on the unbalanced panel data of 16 listed commercial banks in China from 2008 to 2016, and proposed suggestions on standardizing the development of shadow banking, coping with the liquidity risk and strengthening credit risk management. Liu Shengfu et al .(2018) adopted the panel data of 115 commercial banks from 1996 to 2014, constructed a weighted average index and introduced the systematic GMM model to test the relationship between monetary policy and bank risk-taking in the process of interest rate liberalization, and concluded that "a loose monetary policy can stimulate risk-taking behavior of commercial banks while a tight monetary policy can restrict that behavior, but this effect weakens as interest rate liberalization goes deeper". Li Huihua and Ba Shusong (2017) analyzed the current status of interest rate risk management by means of the interest rate sensitivity gap based on the interest rate sensitive data of 13 listed banks from 2007 to 2016, and put forward suggestions on improving the interest rate risk management system, enhancing the monitoring and measurement of interest rate risk and establishing diversified means to control it. To sum up, the risks faced by commercial banks in an environment of interest rate liberalization mainly include interest rate control, profit decline and bankruptcy, etc.

\subsubsection{Research on Interest Rate Liberalization and Impact on the Profit Model of Banks}

Hu Zhijiu and Chu Xiaoyuan (2018) described through theoretical deduction the long-term impact of interest rate liberalization on commercial banks from the perspectives of bankruptcy risk and commercial banks regulation, and deduced that the commercial banks suffering interest rate market-based failure reduced the impact brought by interest spread narrowing through making business innovation. Chen Yirun and Ningyang (2018), Xu Bin and Liu Chuiyong (2018) all employed panel data to analyze the factors influencing the profitability of Chinese commercial banks under interest rate liberalization. Taking 21 commercial banks of different sizes as an example, Chen concluded that the interest rate sensitivity gap ratio, growth capacity and leverage ratio had an impact on the profitability of commercial banks, to different extent according to the different sizes. Based on that analysis, they put forward suggestions to improve gap management, focus on the development of intermediary services and other businesses that are insensitive to interest rate, and strengthen government support for small and medium-sized banks. According to the research results of Xu Bin et al, more attention should be paid to factors such as net interest margin, cost-income ratio, capital adequacy ratio, non-performing loan ratio, reserve ratio, loan-to-deposit ratio, asset size and credit scale, etc, and put forward suggestions on promoting the development of asset business, emphasizing cost management, strengthening interest margin control and increasing non-interest income. Jia Tingting and Zhang Bin (2018) tested the influencing factors of the profit model of banks under interest rate liberalization based on the data of state-controlled commercial banks and joint-stock banks respectively, and the test results proved that bigger spread can bring more income for intermediary services, and then higher profit level for the banks. In addition, change in spread will bring more impact to the profit status of four major state-owned commercial banks than to the joint-stock commercial banks, and they put forward suggestions on improving the profitability for banks.

\section{Method}

This section describes in detail how the study was conducted.

\subsection{Variable Selection}

This paper focuses on the impact of interest rate liberalization on the profitability of the financial sector, thus the key is which variables shall be chosen as a measure of profitability.

\section{(1) ROA}

Financial institutions are profit-making enterprises, and the pursuit of income is a common goal. Return on assets (ROA) is an important indicator to measure the bank's profitability. The formula is: 


$$
\mathrm{ROA}=\text { net profit } / \text { total assets }
$$

Generally speaking, ROA (Return on Assets) and ROE (Return on Equality) are important indicators to measure the profitability of enterprises. ROA is a measure of how much net profit a bank generate from its assets. The higher the index value, the higher the asset utilization efficiency. The reason why such index is chosen as a representative of profitability index is mainly based on the following two points: First, the capital of banks may be in small size. Since the capital adequacy ratio of Chinese banks is very low, the non-performing loan ratio can reach over $20 \%$, and some banks even see a negative net asset value. In this case, if ROE is adopted, it may lead to serious deviation of measurement results. Second, a high ROE may not symbolize high profit of banks, but rather a reflection of insufficient capital and owner's equity. Therefore, the accuracy of ROE in measuring the true profit level of enterprises is still questionable. Generally, ROA is positive, and a higher ROA means better profitability of a bank. Improved profitability of a bank, on the one hand, contributes to enhanced competitiveness and credibility of the bank, so that more customers can be attracted, which in turn strengthens the bank's profitability and risk-taking level, and is conducive to its sound operation, on the other hand, improved profitability can bring more return to investors, and it can also increase the tax revenue of a country, which is conducive to the economic growth.

(2) IRL

The interest rate liberalization index (IRL) is designed and calculated by adopting the measurement method of Wang Shujun and Peng Jiangang (2014). The calculation logic is shown in Figure 2. The formula is:

$$
I R L=\sum q \sum(s \times w)
$$

Currently, China implements an interest rate system which is based on the Central Bank Rate, with the interest rate of financial institutions as the main body and accompanied by market interest rate. The Central Bank Rate refers to the deposit and loan rates of the Central Bank for financial institutions, including the legal deposit-reserve ratio, general deposit rate, refinance rate, and rediscount interest rate. The interest rate of financial institutions refers to the deposit and loan rates of financial institutions for enterprises and individuals. Market interest rate is formed independently by clients of the financial market in capital transaction. The paper builds an index system of interest rate liberalization measurement by taking into account the reality of interest rate system in China and referring to the measurement methods of Wang Shujun and Peng Jiangang (2014). In the index system, the first-level index is composed of two indexes, namely, commercial bank interest rate and financial market interest rate, and the second-level index is composed of the interest rates on deposits and loans in local and foreign currencies representing the commercial bank interest rate system, and the interest rates of interbank lending, bond repurchase, coupon trading and bill discount representing the financial market interest rate system respectively, as shown in table 1 . The results of weight calculation shown in Table 2. The paper will not specify the concrete measurement steps due to limited space here, please contact the author if you need. The calculated interest rate liberalization index is $97.5 \%$ in 2019, indicating that China's interest rate liberalization has reached a rather developed stage by 2019 (as shown in Figure 3).

As it is difficult to accurately judge whether the impact of interest rate liberalization on interest rate spread is linear, the paper introduces the square term IRL2 of interest rate liberalization index to measure whether interest rate liberalization has a nonlinear impact on profitability. 


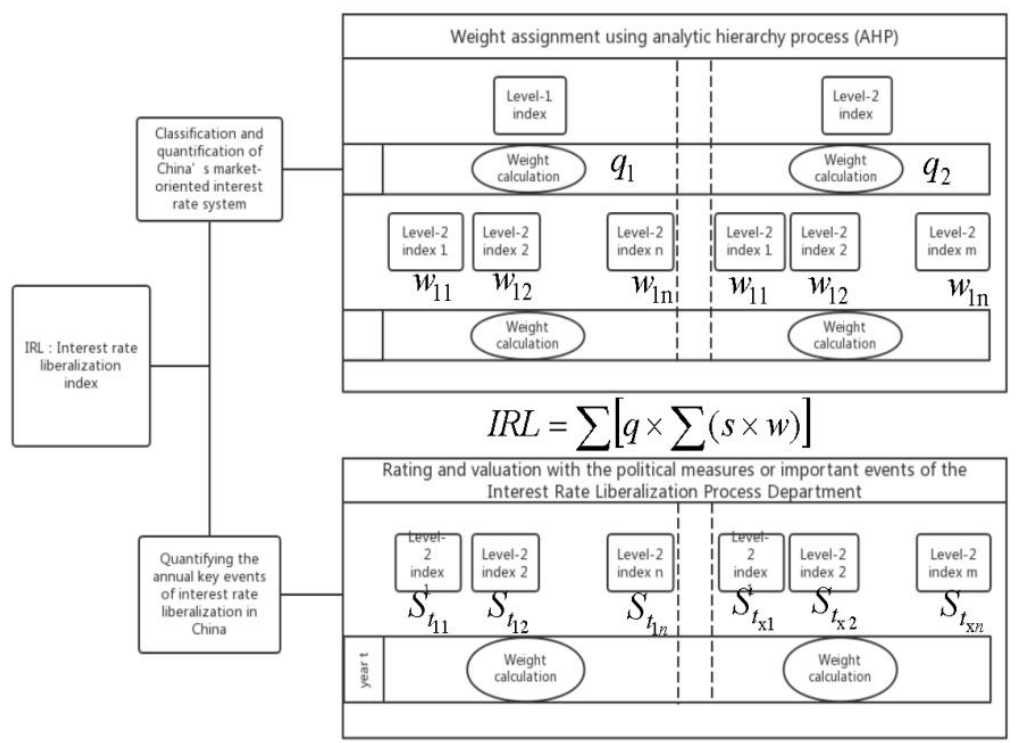

Figure 2. Calculation process diagram of interest rate liberalization measurement system

Table 1. Index system for measure of interest rate liberalization index

\begin{tabular}{ccc}
\hline & Level-1 index & Level-2 index \\
\hline & & RMB loan rate \\
& Commercial bank interest rate & RMB deposit rate \\
Interest rate liberalization & & Foreign currency loan rate \\
\cline { 2 - 3 } & & Foreign currency deposit rate \\
\cline { 2 - 3 } & & Inter-bank lending rate \\
& Financial market interest rate & Bond repurchase rate \\
& & Bond transaction interest rate \\
& Bill discount interest rate \\
\hline
\end{tabular}

Table 2. The results of weight calculation

\begin{tabular}{lcccc}
\hline & Level-1 index & & Level-2 index \\
\hline & & RMB loan rate & 0.375 \\
& Commercial bank & \multirow{2}{*}{0.875} & RMB deposit rate & 0.525 \\
& interest rate & & Foreign currency loan rate & 0.050 \\
Interest rate liberalization & & Foreign currency deposit rate & 0.050 \\
\cline { 2 - 5 } & & Inter-bank lending rate & 0.586 \\
& Financial market & \multirow{2}{*}{0.125} & Bond repurchase rate & 0.107 \\
& interest rate & & Bond transaction interest rate & 0.205 \\
& & Bill discount interest rate & 0.102 \\
\hline
\end{tabular}

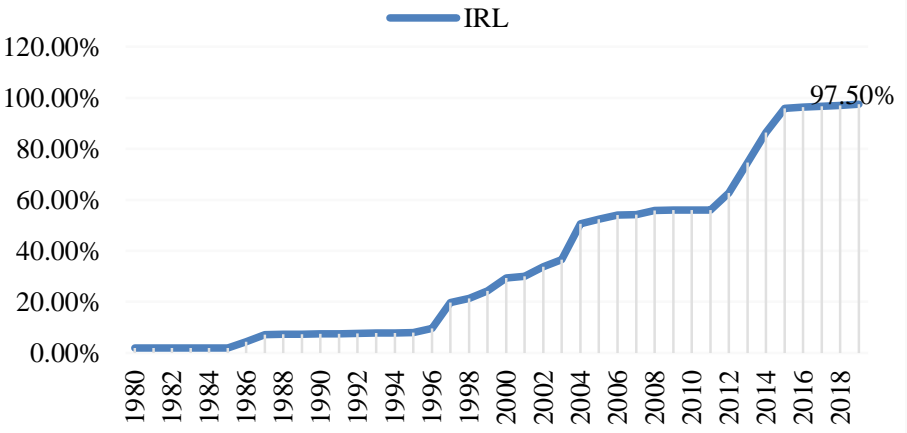

Figure 3. Trend chart of the Interest Rate Liberalization Index (IRL) in China 


\section{(3) NIM}

NIM is a net spread, which is a variable having significant impact on the overall profitability of banks. In the study of economics and finance theories, banks are usually abstracted as a financial intermediary engaged in absorbing deposits and issuing loans, as a result, some scholars regard interest spreads of deposit and loans as the measure of banks' spread level. However, under the circumstances of diversified forms of assets and liabilities, commercial banks cannot only consider interest margin of deposit and loan to fully reflect the interest cost of all fund sources and the interest income of all funds allocation. The interest-bearing assets of modern commercial banks not only refer to loans, but also include bond investment, due from banks, etc., likewise the interest-bearing liabilities refer to not only deposits, but also interbank lending and bond financing. Therefore, such assets and liabilities shall be taken into account when studying the banks' interest margin.

\section{(4) LDR}

LDR stands for loan-to-deposit ratio, the formula of which is:

$$
\text { Loan-to-deposit ratio = loan balance } / \text { deposit balance }
$$

Banks should maintain a moderate loan-to-deposit ratio because, on the one hand, a higher loan-to-deposit ratio would bring better profitability, as the interests paid by the bank to depositors constitute the capital cost of the bank. If the bank pays more interests on deposits than what it receives on loans, it means that the cost of capital is higher relative to income, and then the profitability of bank is reduced, on the other hand, a higher loan-to-deposit ratio does not contribute to better risk resistance. The reason is that banks must maintain proper liquidity to meet customers' demand for withdrawal at any time. Therefore, banks must keep certain deposit reserves. If the loan-to-deposit ratio of a bank is too high, the corresponding part of capital will be relatively insufficient, which may lead to payment crisis for the bank and generate liquidity risk.

\section{(5) AST}

AST stands for assets scale of a bank which measures the size of a bank's assets, and provides a sample classification standard for the subsequent robustness tests. For commercial banks of different sizes, their income level varies greatly, and the larger the size of a bank, the more advantages it will have in terms of human, material and financial resources, thus the income level is relatively high. In this paper, the logarithm of total assets is taken to represent the scale of commercial banks. Relative to the bank's average total assets indicator, taking logarithms of total assets can effectively reduce the volatility of sample, thereby producing more accurate empirical results.

(6)Other control variables

In addition, this paper controls the variables that affect the profitability of banks, including non-interest income (NIR), non-performing loan ratio (NLR), cost-income ratio (CIR), gross domestic product (GDP) and others.

\subsection{Model Building}

Since it is difficult to judge whether the impact of the interest rate liberalization on the profitability is linear through the practical experience, the thesis introduces the quadratic term of the interest rate liberalization index. Nonlinear data model established is shown as follows:

$$
R O A_{i t}=\beta_{0}+\beta_{1} I R L_{i t}+\beta_{2} I R L_{i t}^{2}+\theta X_{i t}+\varepsilon_{i t}
$$

Among them, $i=1,2, \ldots n$ represents the sample number of the security companies. $\mathrm{t}$ stands for the time span. $\beta$, $\theta$ stand for the model parameters to be estimated. $X$ represents all control variables. $\varepsilon$ is the random disturbance term.

In order to reduce heteroscedasticity, the paper logarithmizes some variables other than ratio index.

\subsection{Data Sources}

This paper collected and analyzed the annual data of 16 listed banks in China during 2007-2018 (including Bank of Beijing, Bank of China, Bank of Communications, Minsheng Bank, Nanjing Bank, Ningbo Bank, Ping'an Bank, Pudong Development Bank, Industrial Bank Co.,Ltd, China Merchants Bank, Industrial Commercial Bank of China (ICBC), China Everbright Bank, China Construction Bank, Agricultural Bank of China, Bank of China and China CITIC Bank). The data source is the Wind database and the annual data is from the National Bureau of Statistics website.

Based on the asset size, profitability and social influence of the 16 banks, the paper divides the samples into System Major banks and System Non-major banks. The System Major banks include ICBC, Agricultural Bank 
of China, Bank of China, China Construction Bank, Bank of Communications and China Merchants Bank. The System Non-major banks are mainly joint-stock banks and urban commercial banks, including Beijing Bank, Huaxia Bank, Minsheng Bank, Nanjing Bank, Ningbo Bank, Ping'an Bank, Pudong Development Bank, Industrial Bank, China Everbright Bank and China CITIC Bank. Such joint-stock and urban commercial banks are more market-oriented with more flexible products and active financial innovation. Therefore, it can be inferred that such Non-major banks will be more sensitive to the level of interest rate liberalization.

\section{Results}

\subsection{Empirical Results of the Impact of Interest Rate Liberalization on Banking Profitability}

This paper makes an empirical analysis of the 16 listed commercial banks in China, and the analysis results are listed in Table 3.

Table 3. Empirical results of the impact of interest rate liberalization on banking profitability

\begin{tabular}{|c|c|c|c|c|c|c|}
\hline \multirow{3}{*}{ Variables } & \multicolumn{6}{|c|}{ Return on Assets (ROA) } \\
\hline & $(1)$ & (2) & (3) & (4) & (5) & (6) \\
\hline & OLS & OLS & OLS & FE & $\mathrm{FE}$ & $\mathrm{FE}$ \\
\hline \multirow{2}{*}{$I R L$} & $-0.003 * *$ & $0.078 * * *$ & $0.037 * * *$ & $-0.003 * *$ & $0.078 * * *$ & $0.034 * * *$ \\
\hline & $(0.001)$ & $(0.012)$ & $(0.006)$ & $(0.001)$ & $(0.012)$ & $(0.005)$ \\
\hline \multirow{2}{*}{$I R L^{2}$} & & $-0.001 * * *$ & $-0.000 * * *$ & & $-0.001 * * *$ & $-0.000 * * *$ \\
\hline & & $(0.000)$ & $(0.000)$ & & $(0.000)$ & $(0.000)$ \\
\hline \multirow{2}{*}{ NIM } & & & $0.349 * * *$ & & & $0.233^{* * *}$ \\
\hline & & & $(0.077)$ & & & $(0.061)$ \\
\hline \multirow{2}{*}{$L D R$} & & & $-0.006 * * *$ & & & -0.001 \\
\hline & & & $(0.001)$ & & & $(0.003)$ \\
\hline \multirow{2}{*}{ NIR } & & & $0.013 * * *$ & & & $0.005^{*}$ \\
\hline & & & $(0.002)$ & & & $(0.003)$ \\
\hline \multirow{2}{*}{$N L R$} & & & $-0.017 * * *$ & & & -0.012 \\
\hline & & & $(0.006)$ & & & $(0.008)$ \\
\hline \multirow{2}{*}{$C I R$} & & & $-0.022 * * *$ & & & -0.015 \\
\hline & & & $(0.003)$ & & & $(0.009)$ \\
\hline \multirow{2}{*}{$\ln A S T$} & & & $-0.777 *$ & & & -0.067 \\
\hline & & & $(0.427)$ & & & $(0.349)$ \\
\hline \multirow{2}{*}{$\ln M 2$} & & & $1.458^{*}$ & & & 0.514 \\
\hline & & & $(0.742)$ & & & $(0.677)$ \\
\hline \multirow{2}{*}{$G D P$} & & & 0.029 & & & 0.007 \\
\hline & & & $(0.017)$ & & & $(0.017)$ \\
\hline \multirow{2}{*}{ Constant } & $1.265^{* * *}$ & $-1.604 * * *$ & $-5.694 *$ & $1.265 * * *$ & $-1.604 * * *$ & -5.559 \\
\hline & $(0.104)$ & $(0.473)$ & (3.129) & $(0.080)$ & $(0.460)$ & $(4.159)$ \\
\hline Observations & 192 & 192 & 192 & 192 & 192 & 192 \\
\hline R-squared & 0.048 & 0.174 & 0.614 & 0.084 & 0.302 & 0.538 \\
\hline Number of bank & & & & 16 & 16 & 16 \\
\hline
\end{tabular}

Note. Robust standard error in the brackets. $* * *, * *, *$ refer to significant at $1 \%, 5 \%$, and $10 \%$ significance levels respectively. Since the paper retains only 3 decimal places in the regression results, the numbers following the 3 decimal places are not shown.

In Table 3, columns 1-6 present the estimated results of the impact of interest rate liberalization on bank profitability. Columns 1-3 introduce a common least squares (OLS) hybrid regression without controlling the fixed effect. Columns 4-6 adopt the fixed effect model for estimation while the fixed effect of each bank is controlled. Robust regression is employed for all regressions.

Column 1 shows the impact of interest rate liberalization index (IRL) on the profitability indicator (ROA) of banks without having any variables controlled. The results show that the IRL has a significant negative impact on the profitability of banks. The influence coefficient is -0.003 , which is significant at the significance level of $5 \%$. Column 2, based on column 1, adds the square term IRL2 of the interest rate liberalization index (IRL) to measure whether its impact is non-linear. The results show that IRL2 has a nonlinear impact on bank profitability (ROA) and is significant at the $1 \%$ significance level. Column 3, on the basis of column 2, incorporates all the 
control variables, and the interest rate liberalization index (IRL) coefficient is 0.037 , which is significant at the $1 \%$ significance level. Meanwhile, the other control variables are significant, and the $\mathrm{R}$ value is 0.614 , which justifies most of the variations of ROA, and indicates the validity of the measurement model. Columns 4-6 introduce the fixed effect model. Since $p$ in the $F$ test is 0 when the regression of fixed effect model is misperformed without applying the clustering robust standard error, which strongly reject the original hypothesis, so the regression effect of fixed effect model is better than that of mixed OLS regression. Moreover, $p$ is 0.0269 in Hausman test, so the paper uses fixed effect model instead of random effect model. When fixed effect model is used, the impact of the interest rate liberalization index IRL on the bank profitability indicator ROA is significant, whether the interest rate liberalization index is used alone or in square term. In column 6, when fixed effect model is used with all variables controlled, the interest rate liberalization index has a coefficient of 0.034 for the bank profitability indicator ROA and is significant at the $1 \%$ significance level. This shows that with the progress of interest rate liberalization, the return on assets of commercial banks has been significantly improved. The reason may be that as the interest rate liberalization deepens, the financial market has played a full role in determining the effectiveness of interest rates and financial products. Furthermore, the progress of interest rate liberalization has further stimulated the commercial banks' traditional profit mode which relies on interest income as a major income source, stimulated commercial banks to make financial innovation, so as to continuously introduce the financial products adapted to the market. While serving the social and economic development, interest rate liberalization can increase other income sources for banks such as intermediary services income. With the advance of interest rate liberalization, other banks have also made innovations, which has obviously stimulated change of the banks' operating mode.

\subsection{A Robust Test of the Impact of Interest Rate Liberalization on Commercial Banks' Profitability}

Through the preliminary regression mentioned above, it is found that interest rate liberalization has a significant positive impact on the profitability indicator (ROA) of the banking sector. However, a robust test is necessary to determine whether such result is robust or not. The results are shown in Table 4.

In Table 4, a robust test is conducted on the relationship between interest rate liberalization and banking profitability based on two samples of major and non-major banks. In columns 1-3 of the table, regression experiments are conducted on major banks within the system using a fixed effect model.

Column 1 shows the impact of interest rate liberalization on bank profitability (ROA) without having any variable controlled, but the coefficient is negative and significant at a significance level of $10 \%$, which is possibly due to the absence of controlling other variables. Column 2 controls the square term of the interest rate liberalization index on the basis of column 1, and the resulting coefficient is positive and significant at the level of $1 \%$. Column 3 controls all variables on the basis of column 2, and the interest rate liberalization index and its square term are significant at the $10 \%$ significance level. This indicates that interest rate liberalization is of positive significance to the profitability improvement of major banks in the system. In columns 4-6 of the table, the regression experiment of interest rate liberalization index for profitability ROA of banks is conducted using the sample of non-major banks in the system. The fourth column shows that the interest rate liberalization index has no significant impact on the profitability of ROA without having any variables controlled. In column 5, with the square term of the market index controlled.

The results tell that the interest rate liberalization index has a significant impact on the profitability ROA of banks, and its square term coefficient is negative and significant at the $1 \%$ significance level. Column 6 controls all variables on the basis of column 5, and the interest rate liberalization index coefficient turns to 0.036 and is significant at the $1 \%$ significance level. It shows that the process of interest rate liberalization has positive effect on the profitability of non-major banks in the system. By comparing column 3 with column 6 , we can see that interest rate liberalization has different impact on banks of different nature as interest rate liberalization progresses. In column 3, the interest rate liberalization index IRL has a coefficient of 0.030 (significant at $10 \%$ significance level) but in column 6 it has a coefficient of 0.036 (significant at $1 \%$ significance level). The reason for such difference may be due to the large assets and wide operation areas of major banks in the system as a large number of their customers are enterprises with certain influence in various industries in China. Such major banks enjoy relatively stable customer resources, and they often engage in a large number of government projects and operate monopoly industry loans, so they have a strong dependence on interest income. In column 6 , non-major banks in the system are used for regression, and it is found that interest rate liberalization has a more positive impact on the profitability ROA. This may because that smaller banks necessarily have a stronger market response and financial innovation capability to ensure their competitive advantage in the process of interest rate liberalization. 
Table 4. A robust test of the impact of interest rate liberalization on banking profitability

\begin{tabular}{|c|c|c|c|c|c|c|}
\hline \multirow{4}{*}{ Variables } & \multicolumn{6}{|c|}{ ROA } \\
\hline & \multicolumn{3}{|c|}{ System major banks } & \multicolumn{3}{|c|}{ System non-major banks } \\
\hline & (1) & (2) & (3) & (4) & (5) & (6) \\
\hline & $\mathrm{FE}$ & $\mathrm{FE}$ & $\mathrm{FE}$ & FE & $\mathrm{FE}$ & $\mathrm{FE}$ \\
\hline \multirow{2}{*}{$\operatorname{IRL}$} & $-0.002 *$ & $0.083^{* * *}$ & $0.030^{*}$ & -0.003 & $0.075^{* * *}$ & $0.036^{* * *}$ \\
\hline & $(0.001)$ & $(0.011)$ & $(0.013)$ & $(0.002)$ & $(0.019)$ & $(0.009)$ \\
\hline \multirow{2}{*}{$I R L^{2}$} & & $-0.001 * * *$ & $-0.000 *$ & & $-0.001 * * *$ & $-0.000 * * *$ \\
\hline & & $(0.000)$ & $(0.000)$ & & $(0.000)$ & $(0.000)$ \\
\hline \multirow{2}{*}{$N I M$} & & & $0.252^{* *}$ & & & $0.241^{* * *}$ \\
\hline & & & $(0.098)$ & & & $(0.067)$ \\
\hline \multirow{2}{*}{$L D R$} & & & -0.000 & & & -0.001 \\
\hline & & & $(0.003)$ & & & $(0.004)$ \\
\hline \multirow{2}{*}{ NIR } & & & 0.002 & & & 0.008 \\
\hline & & & $(0.004)$ & & & $(0.005)$ \\
\hline \multirow{2}{*}{$N L R$} & & & -0.009 & & & -0.033 \\
\hline & & & $(0.006)$ & & & $(0.065)$ \\
\hline \multirow{2}{*}{$C I R$} & & & -0.005 & & & -0.019 \\
\hline & & & $(0.008)$ & & & $(0.013)$ \\
\hline \multirow{2}{*}{$\ln A S T$} & & & 0.257 & & & -0.283 \\
\hline & & & $(0.242)$ & & & $(0.523)$ \\
\hline \multirow{2}{*}{$\ln M 2$} & & & 0.151 & & & 0.830 \\
\hline & & & $(0.594)$ & & & $(1.040)$ \\
\hline \multirow{2}{*}{$G D P$} & & & 0.004 & & & 0.015 \\
\hline & & & $(0.013)$ & & & $(0.023)$ \\
\hline \multirow[t]{2}{*}{ Constant } & $1.314 * * *$ & $-1.708^{* * *}$ & -6.701 & $1.236 * * *$ & $-1.541^{*}$ & -5.974 \\
\hline & $(0.075)$ & $(0.407)$ & (4.213) & $(0.122)$ & $(0.714)$ & (6.753) \\
\hline Observations & 72 & 72 & 72 & 120 & 120 & 120 \\
\hline R-squared & 0.084 & 0.475 & 0.770 & 0.087 & 0.254 & 0.489 \\
\hline Number of bank & 6 & 6 & 6 & 10 & 10 & 10 \\
\hline
\end{tabular}

Note. Robust standard error in brackets. ***, **, * are significant at $1 \%, 5 \%$, and $10 \%$ significance level respectively.

\section{Conclusion}

First, interest rate liberalization has different impact on the profitability of different types of commercial banks in China, and it has less impact on state-owned banks but greater impact on joint-stock banks and urban commercial banks. Due to different asset sizes and property rights, the performance of banks to cope with the impact of interest rate liberalization is different, thus interest rate liberalization reform will exert different impact on such banks. China's state-owned banks enjoy large assets and strong business competitiveness. Different from China' s state-owned banks, joint-stock banks and urban commercial banks are in small scale, poor development of intermediary services and weak capability in interest rate risk management. Moreover, the intensified competition in the banking sector brought by interest rate liberalization, the joint-stock banks and urban commercial banks are faced with stronger deposit-taking pressure, higher operating cost and more potential non-performing loans, which make them subject to more severe impact.

Second, the interest rate liberalization reform has limited impact on state-owned banks, but a significant impact on the joint-stock banks. State-owned commercial banks, relying on their advantages of large assets, high brand awareness, well-developed intermediary services and strong capability of financial innovation, have maintained their strong competitiveness and can effectively avoid the adverse impact during the interest rate liberalization reform process. However, China's joint-stock commercial banks and urban commercial banks are in small asset scale with weak competitiveness of traditional deposit and loan business, limited capability of financial innovation and poor interest rate risk management, so they are more vulnerable to the adverse impact of interest rate liberalization reform. With the acceleration of interest rate liberalization reform and increasingly fiercer inter-bank competition, the joint-stock and urban commercial banks will face increased pressure from the rise of deposit interest rate due to their small scale. The increase in deposit interest rate, on the one hand, attracts more savings deposits and increases the accumulation of social capital, thus improves the banks' efficiency at the 
financing stage to a certain extent, but on the other hand, the increase of capital cost will cause joint-stock and urban commercial banks to shift their attention to high-risk and high-return capital investment projects, which may trigger mismatch of asset-liability term structure, higher risk of adverse selection, increased operating cost and rising non-performing loans.

Third, against the backdrop of continuous progress in interest rate liberalization, the asset size, non-performing loans and loan-to-deposit ratio play a certain reverse role to the profitability of Chinese commercial banks, while NIIR, net interest margin, money supply and GDP have certain positive impact on the profitability of Chinese commercial banks.

\section{References}

Bin, X., \& Chuiyong, L. (2018). An Analysis of the Factors Influencing the Profitability of Commercial Banks in China under the Interest Rate Liberalization : Based on the Empirical Study of 16 Listed Commercial Banks. Nanjing Journal of Social Sciences, (03), 31-37. https://doi.org/10.15937/j.cnki.issn1001-8263.2018.03.005

Chengsong, W., \& Wenrui, Z. (2017). Interest Rate Liberalization, Off-Balance-Sheet Activities and the Risks of City Commercial Banks: Empirical Analysis Based on Unbalanced Panel Data. Journal of Beijing University of Chemical Technology (Social Sciences Edition), (04), 1-6. Retrieved from http://kns.cnki.net/KXReader/Detail?TIMESTAMP=637223217173336250\&DBCODE=CJFQ\&TABLENa me $=$ CJFDLAST2018\&FileName $=$ BHGS201704001\&RESULT $=1 \& S I G N=$ Uacb7Ft $\% 2 \mathrm{fchxBaJmqjM3URj}$ DrdRI\%3d

Fengqi, C. (2014). Status and Construction of Benchmark Interest Rate in the Monetary Policy System during the Interest Rate Liberalization Process. Journal of Central University of Finance and Economics, (04), 26-33. Retrieved

from https://kns.cnki.net/KCMS/detail/detail.aspx?dbcode=CJFQ\&dbname=CJFD2014\&filename=ZYCY20140 4005\&v=MTY0NzMzcVRyV00xRnJDVVI3cWZZK2R1RkNqa1VyckJQelRJZDdHNEg5WE1 xNDIGWV1 SOGVYMUx1eFITNORoMVQ=

Hongjin, L. (2015). The Challenges of Interest Rate Liberalization to Banks and the Strategies. Studies of International Finance, (02), 65-76. https://doi.org/10.16475/j.cnki.1006-1029.2015.02.007

Huihua, L., \& Shusong, B. (2017). An Empirical Analysis on the Interest Rate Risk of Different Types of Commercial Banks in China under the Interest Rate Liberalization. Journal of Soochow University(Philosophy \& Social Science Edition, $39(01), \quad$ 101-106. https://doi.org/10.19563/j.cnki.sdzs.2018.01.012

Jinlao, H. (2001). Market-oriented Interest Rate and Risk Control of Commercial Banks. Economic Research Journal, (01), 19-28+94. Retrieved from http://kns.cnki.net/KXReader/Detail?TIMESTAMP=637223240006305000\&DBCODE=CJFD\&TABLENa me $=$ CJFD2001\&FileName=JJYJ200101002\&RESULT=1\&SIGN=EkDLgxD9f6Y53A1QqymIZWKtqsw\% $3 \mathrm{~d}$

Shengfu, L., Xingzhe, Y., \& Yong, H. (2018). Interest Rate Liberalization, Monetary Policy and Bank Risk-taking. Economic Survey, 35(04), 150-157. https://doi.org/10.15931/j.cnki.1006-1096.20180606.002

Shujun, W., \& Jiangang, P. (2014). Research on the Process Measurement and Effect of the Interest Rate Liberalization in China_Empirical Analysis based on Banking Lending Channel. Research in Financial Economics, 29(06), 75-85. Retrieved from https://kns.cnki.net/KCMS/detail/detail.aspx?dbcode=CJFQ\&dbname=CJFDLAST2015\&filename=JIRO20 1406007\&v=MjM4NjBGckNVUjdxZlkrZHVGQ2prVTd6Tkx5VFpZYkc0SDIYTXFZOUZZNFI4ZVgxT

Shusong, B., Min, Y., \& Yuexiang, W. (2013). Analysis of the Impact of Interest Rate Liberalization on Commercial Banks in China. Journal of Huazhong Normal University (Humanities and Social Sciences), (04), 27-37. Retrieved from http://kns.cnki.net/KXReader/Detail?TIMESTAMP=637223239140680000\&DBCODE=CJFQ\&TABLENa me $=$ CJFD2012\&FileName $=$ HZSD201205006\&RESULT $=1 \& S I G N=b Q B 9 i B Y \% 2 f A 6 v v E K \% 2 f V b 27 Z A d P$ SLg4\%3d

Tingting, J., \& Bin, Z. (2018). Study on the Factors Influencing the Profit Model of Commercial Banks under the Background of Interest Rate Liberalization: Empirical Analysis based on Comparison between States-owned Commercial Banks and Joint-stock Commercial Banks. Journal of Changchun University of Science and Technology (Social Sciences Edition), 31(04), 97-102. Retrieved from 
http://kns.cnki.net/KXReader/Detail?TIMESTAMP=637223237101930000\&DBCODE=CJFQ\&TABLENa me $=$ CJFDLAST2018\&FileName $=$ CCLG201804019\&RESULT $=1 \& S I G N=Q b s b l p X B T C 30 K L i f Y i z D L O j 1$ $\mathrm{HO} 8 \% 3 \mathrm{~d}$

Xionghua, T., \& Mingjue, C. (2013). Measure and Reform Implications of China's Interest Rate Liberalization. Journal of Zhongnan University of Economics and Law, (03), 74-79 + 160. Retrieved from https://kns.cnki.net/KCMS/detail/detail.aspx?dbcode=CJFQ\&dbname=CJFD2013\&filename=ZLCJ201303 010\&v=MDgzNzZyV00xRnJDVVI3cWZZK2R0RkNqblZiL0JQeUhJWkxHNEg5TE1ySTIFWklSOGVY MUx1eFITNORoMVQzcVQ=

Yirun, C., \& Ningyang. (2018). On the Factors Influencing the Profitability of Commercial Banks in China under the Condition of Interest Rate Liberalization: Take 21 Commercial Banks of Different Scales for Example. Shanghai Finance, (07), 68-74. https://doi.org/10.13910/j.cnki.shjr.2018.07.011

Zhijiu, H., \& Xiaoyuan, C. (2018). Study of Long-Term Effect of Interest Rate Liberalization on Commercial Banks. Journal of Central University of Finance \& Economics, (06), 48-57. https://doi.org/10.19681/j.cnki.jcufe.2018.06.005

\section{Copyrights}

Copyright for this article is retained by the author(s), with first publication rights granted to the journal.

This is an open-access article distributed under the terms and conditions of the Creative Commons Attribution license (http://creativecommons.org/licenses/by/4.0/). 